\title{
Identification of fungi in Tunisian olive orchards: characterization and biological control potential
}

\author{
Houda Gharsallah ${ }^{1 *}$, Ines Ksentini ${ }^{1}$, Sourour Naayma ${ }^{1}$, Karama Hadj Taieb ${ }^{1,2}$, Nour Abdelhedi ${ }^{1}$, Christina Schuster ${ }^{3,4}$, \\ Mohamed Ali Triki ${ }^{1}$, Mohieddine Ksantini ${ }^{1}$ and Andreas Leclerque ${ }^{3,4}$
}

\begin{abstract}
Background: Olive production is the main agricultural activity in Tunisia. The diversity of fungi was explored in two different olive groves located in two distant geographical zones in Sfax (Tunisia) with different management practices.

Results: Fungal isolation was made from soil and the major olive tree pests, namely the Olive fly, Bactrocera oleae Gmelin (Diptera: Tephritidae), and the Olive psyllid, Euphyllura olivina Costa (Homoptera: Psyllidae). A total of 34 fungal isolates were identified according to their phenotypic, genotypic, biochemical and biological activities. Twenty fungal species were identified belonging to six different genera (Alternaria, Aspergillus, Cladosporium, Fusarium, Lecanicillium and Penicillium) by the analysis of their ITS1-5.8S-ITS2 ribosomal DNA region. Different bioassays performed in this work revealed that 25/34 (73.5\%) of the identified fungal isolates showed an entomopathogenic and/or antagonistic activity, 9/34 (26.5\%) of them displayed phytopathogenic features.

Conclusions: Fungal species that showed entomopathogenic and/or antagonistic potentialities and that are nonphytopathogenic, $(17 / 34 ; 50 \%)$ of our fungal isolates, could be explored for olive protection against fungal diseases and pests, and might have a future application as biocontrol agents.
\end{abstract}

Keywords: Biological control, Fungi, Insect pests, Antagonism, Phytopathogenicity, Entomopathogenicity

\section{Background}

Biological control is an often effective and environmentally friendly method for controlling pests and phytopathogens by a natural enemy and/or formulation. Some of these biological control methods as, e.g., combating insect pest species by pathogens and plant diseases by antagonists, were found efficient [1-3]. However, effectiveness is strongly related to the biological control agent's origin, with native ones being more efficient and often achieve better results $[4,5]$. Thus, it is important to ensure that the screening for insect pest pathogens

\footnotetext{
* Correspondence: houda_gharsallah@yahoo.fr

'Laboratory of Improvement and Protection of Genetic Resources of Olive

Tree, Tunisian Olive Institute, University of Sfax, Airport Road, P.B. 1087, 3000 Sfax, Tunisia

Full list of author information is available at the end of the article
}

and phytopathogenic antagonists is done in their original spreading areas.

The olive tree, Olea europaea L. (Equisetopsida, Lamiales), cultivation is among the important crops in the world [6]. Widespread areas are occupied by olive groves in the Mediterranean basin countries including Tunisia which ranks in the fourth position in terms of virgin olive oil production [6, 7]. In Tunisia, with approximately 8.5 million olive trees spreading over almost 1.7 million ha, Sfax governorate has the largest surface dedicated to olive cultivation, representing $18.7 \%$ of the national olive cultivation area [8], and ensuring $33 \%$ of the Tunisian olive oil production [9]. In this governorate, olive cultivation has as a consequence, considerable

C C The Author(s). 2020 Open Access This article is licensed under a Creative Commons Attribution 4.0 International License, which permits use, sharing, adaptation, distribution and reproduction in any medium or format, as long as you give appropriate credit to the original author(s) and the source, provide a link to the Creative Commons licence, and indicate if changes were made. The images or other third party material in this article are included in the article's Creative Commons licence, unless indicated otherwise in a credit line to the material. If material is not included in the article's Creative Commons licence and your intended use is not permitted by statutory regulation or exceeds the permitted use, you will need to obtain permission directly from the copyright holder. To view a copy of this licence, visit http://creativecommons.org/licenses/by/4.0/ The Creative Commons Public Domain Dedication waiver (http://creativecommons.org/publicdomain/zero/1.0/) applies to the data made available in this article, unless otherwise stated in a credit line to the data. 
economic impact and displays social, environmental and landscape significance.

Unfortunately, these olive orchards are continuously damaged by major olive insect pests, namely the olive fly, Bactrocera oleae Gmelin (Diptera: Tephritidae), the olive moth, Prays oleae Bernard (Lepidoptera: Yponomeutidae), and the olive psyllid, Euphyllura olivina Costa (Homoptera: Psyllidae), which may cause high economic losses [10-13]; and plant pathogens such as Fusicladium oleaginum (Castagne) Ritschel \& U. Braun (Dothideomycetes), Pseudocercospora cladosporioides (Sacc.) U. Braun (syn. Cercospora cladosporioides (Sacc.) (Dothideomycetes), or Verticillium dahliae Kleb (Sordariomycetes) $[14,15]$. The control of these pests and pathogens has been based on the application of chemical pesticides - e.g. those based on synthetic pyrethroids characterized by their damaging effects to the ecosystems [16] as, e.g., pest-resistance problems [17], sideeffects on auxiliary fauna $[18,19]$ and human health [20]. However, these practices are being replaced by biological control methods. Among the possible biological control methods, the use of entomopathogenic and the antagonistic fungi is considered as a promising strategy. The entomopathogenic activity of fungi as well as their antifungal activity depend on several factors including hydrolytic enzymes as amylases, proteases, lipases, chitinases, esterases, glucanases, and catalases [21-23]. Insects and fungi are embroiled in complex interactions between them. Enzymes such as amylases, proteases and lipases are implicated in the infective process of the insect by entomopathogenic fungi. In fact, lipases are involved in the adhesion of fungal spores on the insect cuticle, which is a mandatory pre-step that initiates the degradation of fatty acids and alkenes in the insect epicuticle [21]. Proteases intervene in the degradation of the proteinaceous material of insect and are considered as the most important enzymes for the infective process [22]. The amylase activity degrading glycogen of the insect tissues allows its use for the growth and invasion of entomopathogenic fungi [24].

In the present study, the mycobiota associated with olive trees and pests were investigated as part of a research effort targeting ecosystem-friendly approaches for olive tree pest and pathogen management. Fungal isolates from olive orchards were characterized by molecular methods, and investigated for their enzymatic, antifungal, entomopathogenic and phytopathogenic activities.

\section{Results}

\section{Systematic characterization of the fungal isolates}

Fungi isolation from the insect pest cadavers and soil samples in Taous and Torba allowed the identification of 34 fungal strains (Table 1, Fig. S1). Twenty fungal species were identified belonging to 6 different genera
(Alternaria, Aspergillus, Cladosporium, Fusarium, Lecanicillium, Penicillium) and 5 families (Trichocomaceae, Pleosporaceae, Nectriaceae, Davidiellaceae, Cordycipitiaceae) by the comparison of their ITS1-5.8S-ITS2 sequences. All the 34 nucleotide sequences obtained from this region represented high degrees of identity with fungal ITS sequences available in the GenBank Database (scores $>98 \%$ ).

The most strongly represented fungal taxonomic family was the Trichocomaceae. This family accounted for $22 / 34$ (i.e. $64.7 \%$ ) of the identified fungal strains that were assigned to 14 species. Aspergillus ( $N=8$ species), Penicillium ( $N=6$ species) and Cladosporium ( $N=3$ species) were the most prevalent genera, whereas Cladosporium cladosporioides ( $N=4$ isolates) and Aspergillus ustus $(\mathrm{N}=$ 3 isolates) were most prevalent at the species level.

The experimental plot of Taous that was managed conventionally and under artificial irrigation, displayed greater fungal richness than the Torba plot that was managed biologically and under rain-fed conditions. In fact, in the Taous plot, among a total of 17 fungal isolates obtained; 12 varied species were identified, belonging to 6 genera and 5 families. The family Trichocomaceae representing $47.0 \%(8 / 17)$ and the genus Aspergillus representing 29.4\% (5/17) of the identified fungi were prevalent in this plot. Three genera were typically found only in the Taous plot, namely Alternaria, Fusarium and Lecanicillium.

Olive fly and olive psyllid pest cadavers displayed the greatest species richness, with 16 distinct species belonging to 6 genera and 5 families. Trichocomaceae was the most frequently detected family accounting for $53.8 \%$ $(14 / 24)$ of the total of insect-derived fungal isolates, whereas Penicillium (9/24; 37.5\%) and Aspergillus (5/24; $20.8 \%)$ were the most prevalent genera (Fig. S2).

The majority of fungal species (90\%) tended to appear in very low numbers (singletons and doubletons) while only two taxa $(10 \%)$ were represented by three or more isolates. The fungal diversity was evaluated through Simpson's Index and values of this index showed that the two sites (Torba and Taous) have the same fungal diversity (0.95). The fungal biodiversity analysis with respect to the comparison between species of insects and soil, demonstrated that insects (0.96) had greater fungal diversity than soil (0.86).

\section{Screening for specific enzymes production}

The 34 collected isolates were evaluated for their enzymatic activities, namely the amylase, protease and lipase enzymes (Fig. 1). Among these, amylase activities were most widespread being present in 58.8\% (20/34) of the isolates. Most of amylase producing fungi belonged to the genera Aspergillus and Penicillium. Strains isolated from soil produced significantly more lipase than other 
Table 1 Fungal isolated from different olive orchards identified by sequence comparison with the BLASTn (NCBI GenBank database)

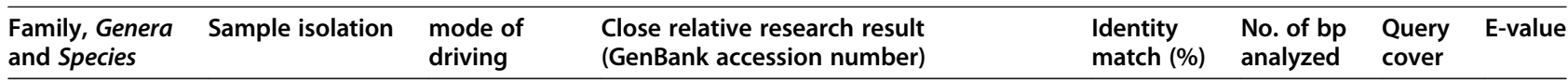

\section{Trichocomaceae}

Penicillium

Penicillium chrysogenum

F3 Insect

F49' Insect

Penicillium crustosum

F14 Insect

F33 Insect

Penicillium freii

F29 Insect

Penicillium pinophilum

$\begin{array}{ll}\text { F36 } & \text { Soil } \\ \text { F38 } & \text { Insect }\end{array}$

Penicillium polonicum

$$
\text { F34 Insect }
$$$$
\text { F41 Insect }
$$

Penicillium verruculosum

$$
\text { F30 Insect }
$$

Aspergillus

Aspergillus calidoustus

$\begin{array}{ll}F 1^{\prime} & \text { Soil } \\ \text { F25 } & \text { Soil }\end{array}$

Aspergillus nidulans

$$
\text { F23 Soil }
$$

Aspergillus niger

$$
\text { F46 Insect }
$$

Aspergillus ochraceus

$\begin{array}{ll}\text { F21 } & \text { Insect } \\ \text { F57 } & \text { Insect }\end{array}$

Aspergillus pseudodeflectus

$$
\text { F13 Soil }
$$

Aspergillus tamarii

$$
\text { F60 Insect }
$$

Aspergillus terreus

$$
\text { F58 Insect }
$$

Aspergillus ustus

$\begin{array}{ll}\text { F22 } & \text { Soil } \\ \text { F26 } & \text { Soil } \\ \text { F27 } & \text { Soil }\end{array}$

\section{Davidiellaceae}

Cladosporium

Cladosporium cladosporioides

$$
\text { F18 Insect }
$$

Biological
Biological

Penicillium chrysogenum (KY445804.1)

Penicillium chrysogenum (KC811007.1)

Biological

Penicillium crustosum (MF072639.1)

Conventional Penicillium crustosum (MG596635.1)

Conventional

Penicillium freii (KY859388.1)

Biological

Penicillium pinophilum (MF806019.1)

Biological

Penicillium pinophilum (MF686817.1)

Biological

Penicillium polonicum (KX944174.1)

Biological

Penicillium polonicum (KX944174.1)

Conventional

Penicillium verruculosum (KY921956.1)

Biological

Aspergillus calidoustus (KX610170.1)

Biological

Aspergillus calidoustus (KX610170.1)

Biological

Aspergillus nidulans (MG734752.1)

Conventional

Aspergillus niger (MG759551.1)

Conventional

Conventional

Aspergillus ochraceus (KX463003.1)

Aspergillus ochraceus (LT596572.1)

Biological

Aspergillus pseudodeflectus (LN482409.1)

100

Conventional

Aspergillus tamarii (MG682505.1)

Conventiona

Aspergillus terreus (KX090315.1)

Biological

Biological

Biological

Aspergillus ustus (KF860885.1)

Aspergillus ustus (KF860885.1)

Aspergillus ustus (KF860885.1)

100

100

100

100

100

100

99

100

100

100

99

100

99

99

$\begin{array}{ll}100 & 3 \\ 98 & 100\end{array}$

$\begin{array}{llll}99 & 170 & 98 \% & 2 \mathrm{e}-69 \\ 100 & 130 & 100 \% & 2 \mathrm{e}-51\end{array}$

120

$100 \% \quad 2 e-51$

330

120

100\% 5e-162

$100 \% \quad 2 \mathrm{e}-51$

110

120

89\% 1e-65

$100 \% \quad 2 e-51$

130

$100 \% \quad 2 e-51$

150

100

$100 \%$

$2 e-74$

$100 \% \quad 2 \mathrm{e}-51$

120

$87 \% \quad 6 e-54$

120

$100 \% \quad 3 e-50$

170

125

98\% 7e-79

$100 \% \quad 2 \mathrm{e}-51$

100

$100 \% \quad 8 e-29$

230

$98 \% \quad 2 \mathrm{e}-120$

150

$100 \% \quad 9 e-78$

$98 \quad 100$

$70 \% \quad 8 \mathrm{e}-21$

120

94\% 6e-27

120

$90 \% \quad 2 e-31$

Conventional

Cladosporium cladosporioides (KX255861.1)

99

150

$100 \% \quad 6 e-71$ 
Table 1 Fungal isolated from different olive orchards identified by sequence comparison with the BLASTn (NCBI GenBank database) (Continued)

\begin{tabular}{|c|c|c|c|c|c|c|c|}
\hline $\begin{array}{l}\text { Family, Genera } \\
\text { and Species }\end{array}$ & Sample isolation & $\begin{array}{l}\text { mode of } \\
\text { driving }\end{array}$ & $\begin{array}{l}\text { Close relative research result } \\
\text { (GenBank accession number) }\end{array}$ & $\begin{array}{l}\text { Identity } \\
\text { match (\%) }\end{array}$ & $\begin{array}{l}\text { No. of bp } \\
\text { analyzed }\end{array}$ & $\begin{array}{l}\text { Query } \\
\text { cover }\end{array}$ & E-value \\
\hline F40 & Insect & Conventional & Cladosporium cladosporioides (JX982429.1) & 100 & 120 & $100 \%$ & $2 e-51$ \\
\hline $\mathrm{F} 50^{\prime}$ & Insect & Biological & Cladosporium cladosporioides (KT898681.1) & 100 & 115 & $100 \%$ & $4 e-48$ \\
\hline F52' & Insect & Conventional & Cladosporium cladosporioides (KY381824.1) & 99 & 335 & $100 \%$ & 2e-149 \\
\hline \multicolumn{8}{|c|}{ Cladosporium halotolerans } \\
\hline F45 & Insect & Biological & Cladosporium halotolerans (KY445825.1) & 99 & 120 & $100 \%$ & $8 e-50$ \\
\hline \multicolumn{8}{|c|}{ Cladosporium sphaerospermum } \\
\hline F17 & Insect & Biological & Cladosporium sphaerospermum (KY046240.1) & 99 & 250 & $100 \%$ & $5 e-105$ \\
\hline $\mathrm{F} 2 \mathrm{O}^{\prime}$ & Insect & Conventional & Cladosporium sphaerospermum (KY460929.1) & 98 & 200 & $100 \%$ & $3 e-100$ \\
\hline \multicolumn{8}{|l|}{ Nectriaceae } \\
\hline \multicolumn{8}{|l|}{ Fusarium } \\
\hline \multicolumn{8}{|c|}{ Fusarium solani-like } \\
\hline F16 & Insect & Conventional & Fusarium solani (KX235324.1) & 99 & 200 & $99 \%$ & $1 e-55$ \\
\hline F59 & Insect & Conventional & Fusarium solani (MG757634.1) & 100 & 100 & $100 \%$ & $2 e-51$ \\
\hline \multicolumn{8}{|l|}{ Pleosporaceae } \\
\hline \multicolumn{8}{|l|}{ Alternaria } \\
\hline \multicolumn{8}{|c|}{ Alternaria consortialis } \\
\hline F10 & Insect & Conventional & Alternaria consortialis (KY458489.1) & 99 & 160 & $100 \%$ & $2 e-51$ \\
\hline F50 & Insect & Conventional & Alternaria consortialis (KY458489.1) & 100 & 140 & $100 \%$ & $2 e-51$ \\
\hline \multicolumn{8}{|l|}{ Cordycipitaceae } \\
\hline \multicolumn{8}{|l|}{ Lecanicillium } \\
\hline \multicolumn{8}{|c|}{ Lecanicillium aphanocladii } \\
\hline$F 28^{\prime}$ & Insect & Conventional & Lecanicillium aphanocladii (KP689216.1) & 99 & 250 & $100 \%$ & $1 e-132$ \\
\hline
\end{tabular}

isolates as, e.g., derived from olive fly and olive psyllid cadavers $(p=0.034)$.

Proteolytic activity was present in $23.5 \%(8 / 34)$ of the isolated fungi which showed their ability to produce extracellular protease by the degradation halos of casein on solid medium. Aspergillus was the genus able to degrade casein in all samples, with (statistically not significant) differences in the protease activity between isolates.

A high percentage of fungal isolates $67.6 \%$ (23/34) displayed an ability to produce extracellular lipase as determined by fluorescent halos around their colonies after irradiation with UV light. Among these lipase-producing isolates, $47.8 \%(11 / 23)$ were identified as Aspergillus, $26.1 \%(6 / 23)$ as Penicillium and $17.4 \%(4 / 23)$ as Cladosporium. Aspergillus was significantly the most abundant genus which comprised $75 \%(6 / 8)$ of the protease- and $47.8 \%(11 / 23)$ of the lipase-producing isolates with respectively significant differences of $(p=0.01)$ and $(p=$ 0.03 ), respectively, to the representation of other genera.

\section{Antagonistic activity in vitro}

The 34 fungi of our collection were evaluated for their antifungal activity using dual-culture tests against six reference strains representing the five fungal species Aspergillus calidoustus, Penicillium chrysogenum (two strains), Alternaria consortialis, Aspergillus pseudodeflectus and Aspergillus tamarii (Table 2). Almost two thirds of the olive tree or olive pest derived fungal isolates $(22 / 34,64.7 \%)$ belonging to 6 different genera and 16 species inhibited mycelial growth of at least one reference strain as compared with the untreated control. Isolates Penicillium chrysogenum F49', Aspergillus ochraceus F57 and Fusarium solani-like F59 showed the highest antifungal activity $(4 / 6,66.7 \%)$ in terms of the number of inhibited reference strains, and Penicillium chrysogenum F49' presented the strongest antifungal activity by producing the largest inhibition zones against 4 target fungi. Among the 34 isolates, $23.5 \%(8 / 34)$, $35.3 \%$ (12/34), $41.2 \%(14 / 34), 5.9 \%$ (2/34), 8.8\% (3/34), and $23.5 \%(8 / 34)$ displayed antagonistic activity against $A$. calidoustus, $P$. chrysogenum $1, A$. consortialis, $A$. pseudodeflectus, $P$. chrysogenum 2 and $A$. tamarii, respectively. The antibiosis was significantly observed as mode of action employed by both Fusarium and Lecanicillium fungal strains assayed against the $A$. consortialis reference strain ( $p=0.046$ ). The dual culture of $P$. chrysogenum F49' and $A$. consortialis recorded the highest inhibition zone. 


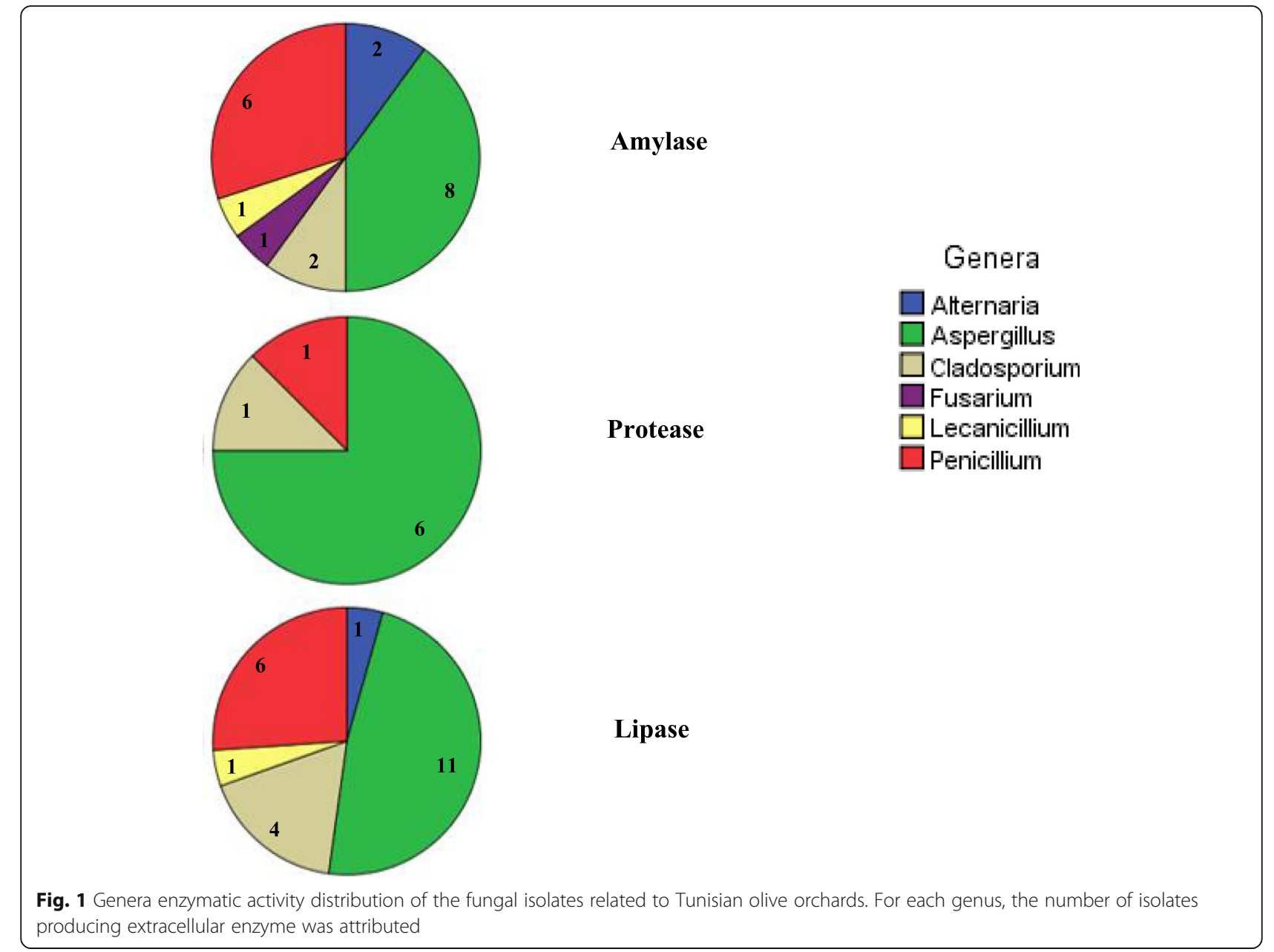

\section{Entomopathogenic activity}

The 16 tested fungal isolates displayed significant differences in their entomopathogenic activity as determined 7 days after treatment by the number of dead fourth instar larvae fed on a diet containing a fungal suspension $\left(10^{7}\right.$ Conidia/ml), with $p<0.05$ (Fig. 2). One-way ANOVA was done to test significant differences between the means of mortality percentage. Results studying the effect of the treatment are significant $(p<0.05)$ as compared to the negative control. The mortality percentage of L4 larvae fed semolina contaminated with the fungal suspension varied from $13 \%$ up to $100 \%$. From our fungal isolates, Aspergillus pseudodeflectus $\mathrm{F} 13$ and Lecanicillium aphanocladi F28' were the most pathogenic with mortality rates of 100 and $93.3 \%$, respectively, followed by Cladosporium sphaerospermum F17 (86.6\%). Treated cadavers incubated in adequate conditions resulted in confirming the fungal infection causing the death of the insect.

\section{Phytopathogenic activity}

The study of the phytopathogenic activity of 34 distinct fungal isolates, using the excised shoot assays, was evaluated in terms of browning on cortex and vascular tissues 28 days after inoculation. Whereas, 11.8\% (4/34) of the tested isolates, namely Penicillium crustosum F14, Penicillium polonicum F34, Aspergillus ochraceus F57 and Aspergillus terreus F58, have produced cortex browning compared to control shoots, $14.7 \%$ (5/34), more exactly Alternaria consortialis F10, Aspergillus ochraceus F21, Aspergillus ustus F22, Aspergillus nidulans F23 and Alternaria consortialis F50, were found to cause vascular tissue browning (Table 3).

\section{Discussion}

\section{Richness of fungal taxa}

In this work, the diversity of fungi isolated from major olive pests and soil samples was evaluated. The molecular identification using the ITS marker presents 20 fungal species, belonging to 6 genera and 5 families. To support the identification of Fusarium species, more genetic markers should be included. In fact, ITS did not present a good molecular marker to identify species of Fusarium since this region is rather well-conserved in the genus [25]. 
Table 2 Antagonistic activity of our collected fungal isolates against 6 pathogenic fungal isolates

\begin{tabular}{|c|c|c|c|c|c|c|}
\hline \multirow{2}{*}{$\begin{array}{l}\text { Antagonistic } \\
\text { Fungal isolates }\end{array}$} & \multicolumn{6}{|c|}{ Fungal pathogens } \\
\hline & $\begin{array}{l}\text { Aspergillus } \\
\text { calidoustus }\end{array}$ & $\begin{array}{l}\text { Penicillium } \\
\text { chrysogenum } 1\end{array}$ & $\begin{array}{l}\text { Alternaria } \\
\text { consortialis }\end{array}$ & $\begin{array}{l}\text { Aspergillus } \\
\text { pseudodeflectus }\end{array}$ & $\begin{array}{l}\text { Penicillium } \\
\text { chrysogenum2 }\end{array}$ & $\begin{array}{l}\text { Aspergillus } \\
\text { tamarii }\end{array}$ \\
\hline \multicolumn{7}{|c|}{ Penicillium chrysogenum } \\
\hline F3 & + & - & ++ & - & - & - \\
\hline F49' & + & ++ & +++ & +++ & - & - \\
\hline \multicolumn{7}{|c|}{ Penicillium crustosum } \\
\hline F14 & +++ & + & +++ & - & - & - \\
\hline F33 & - & - & - & - & - & - \\
\hline \multicolumn{7}{|l|}{ Penicillium freii } \\
\hline F29 & - & - & - & - & - & - \\
\hline \multicolumn{7}{|c|}{ Penicillium pinophilum } \\
\hline F36 & - & ++ & ++ & - & - & +++ \\
\hline F38 & - & - & - & - & - & - \\
\hline \multicolumn{7}{|c|}{ Penicillium polonicum } \\
\hline F34 & ++ & - & +++ & - & - & - \\
\hline F41 & + & - & - & - & - & ++ \\
\hline \multicolumn{7}{|c|}{ Penicillium verruculosum } \\
\hline F30 & - & - & - & - & - & - \\
\hline \multicolumn{7}{|c|}{ Aspergillus calidoustus } \\
\hline$F 1^{\prime}$ & - & ++ & - & - & - & - \\
\hline F25 & - & +++ & - & - & - & - \\
\hline \multicolumn{7}{|c|}{ Aspergillus nidulans } \\
\hline$F 23$ & - & - & ++ & - & - & - \\
\hline \multicolumn{7}{|l|}{ Aspergillus niger } \\
\hline F46 & + & + & ++ & - & - & - \\
\hline \multicolumn{7}{|c|}{ Aspergillus ochraceus } \\
\hline$F 21$ & - & + & - & - & - & ++ \\
\hline F57 & - & + & + & - & + & + \\
\hline \multicolumn{7}{|c|}{ Aspergillus pseudodeflectus } \\
\hline F13 & ++ & +++ & + & - & - & - \\
\hline \multicolumn{7}{|l|}{ Aspergillus tamarii } \\
\hline F60 & - & - & ++ & ++ & + & - \\
\hline \multicolumn{7}{|l|}{ Aspergillus terreus } \\
\hline F58 & - & - & + & - & - & - \\
\hline \multicolumn{7}{|l|}{ Aspergillus ustus } \\
\hline F22 & - & - & - & - & - & - \\
\hline F26 & - & +++ & - & - & - & ++ \\
\hline$F 27$ & - & +++ & - & - & - & ++ \\
\hline \multicolumn{7}{|c|}{ Cladosporium cladosporioides } \\
\hline F18 & - & - & - & - & - & - \\
\hline $\mathrm{F} 40$ & - & - & - & - & - & - \\
\hline $\mathrm{F} 50^{\prime}$ & - & - & - & - & - & - \\
\hline F52' & - & - & - & - & - & - \\
\hline
\end{tabular}


Table 2 Antagonistic activity of our collected fungal isolates against 6 pathogenic fungal isolates (Continued)

\begin{tabular}{|c|c|c|c|c|c|c|}
\hline \multirow{2}{*}{$\begin{array}{l}\text { Antagonistic } \\
\text { Fungal isolates }\end{array}$} & \multicolumn{6}{|c|}{ Fungal pathogens } \\
\hline & $\begin{array}{l}\text { Aspergillus } \\
\text { calidoustus }\end{array}$ & $\begin{array}{l}\text { Penicillium } \\
\text { chrysogenum1 }\end{array}$ & $\begin{array}{l}\text { Alternaria } \\
\text { consortialis }\end{array}$ & $\begin{array}{l}\text { Aspergillus } \\
\text { pseudodeflectus }\end{array}$ & $\begin{array}{l}\text { Penicillium } \\
\text { chrysogenum2 }\end{array}$ & $\begin{array}{l}\text { Aspergillus } \\
\text { tamarii }\end{array}$ \\
\hline \multicolumn{7}{|c|}{ Cladosporium halotolerans } \\
\hline F45 & - & - & - & - & - & - \\
\hline \multicolumn{7}{|c|}{ Cladosporium sphaerospermum } \\
\hline F17 & - & - & - & - & - & - \\
\hline $\mathrm{F} 2 \mathrm{O}^{\prime}$ & - & - & - & - & - & - \\
\hline \multicolumn{7}{|c|}{ Fusarium solani-like } \\
\hline F16 & - & - & ++ & - & - & - \\
\hline F59 & - & ++ & ++ & - & + & ++ \\
\hline \multicolumn{7}{|c|}{ Alternaria consortialis } \\
\hline F10 & +++ & - & - & - & - & - \\
\hline F50 & - & - & - & - & - & + \\
\hline \multicolumn{7}{|c|}{ Lecanicilliumaphanocladii } \\
\hline F28 & - & - & + & - & - & - \\
\hline
\end{tabular}

The activity was detected for clear halo zones around the colonies. The inhibition zone diameters varied from 0 to $40 \mathrm{~mm}$. The inhibition zones diameterincrease concurrently. + [5-10], ++ [11-20], +++ [21-40], - no zones of inhibition

The genera Aspergillus and Penicillium were most abundant in the collected samples comprising $64.7 \%$ $(22 / 34)$ at the strain and $70 \%(14 / 20)$ at the species level independently on production guidelines. These observations are in line with studies emphasizing the largest widespread of Penicillium and Aspergillus identified as the dominant genera in most of the ecosystems and were the most ubiquitous fungal species in nature (soils, plants and agricultural communities) [13, 26-28].
The identification of this number of fungal taxa describing enzymatic, antagonistic, phytopathogenic and entomopathogenic features was variable. These findings are in line with previous studies showing that the fungal diversity was maintained under organic and integrated production guidelines. In fact, in the literature it was reported that the expected fungal diversity performed on a conventional orchard would have been lower than organic and integrated orchards which creates a healthier

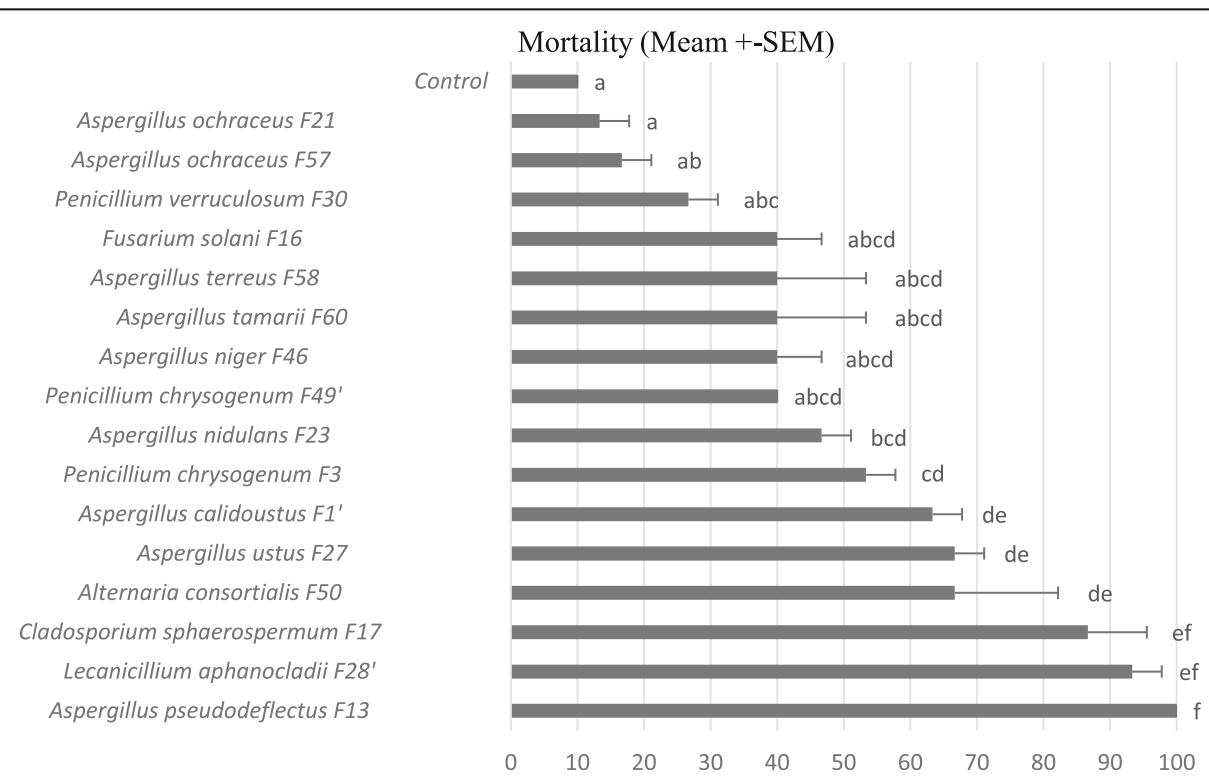

Fig. 2 Mean mortality rate of forth instar Ephestia kuehniella larvae fed with semolina mixed with conidial suspension of fungi at concentration adjusted to $10^{7}$ conidia/ml, 7 days after treatment. Bars followed by letters are significantly different $(p<0.05)$, according to Tukey test 
Table 3 Phytopathogenic activity, of fungal isolates showing cortex browning or vascular tissue browning, using excised shoot assays 28 days after inoculation based on tissues browning

\begin{tabular}{lll}
\hline $\begin{array}{l}\text { Fungal isolates displaying } \\
\text { phytopathogenic activity }\end{array}$ & \multicolumn{2}{l}{ Phytopathogenic activity } \\
\cline { 2 - 3 } & $\begin{array}{l}\text { Cortex } \\
\text { Browning }\end{array}$ & $\begin{array}{l}\text { Vascular Tissues } \\
\text { Browning }\end{array}$ \\
\hline Penicillium crustosum F14 & + & - \\
Penicillium polonicum F34 & + & - \\
Aspergillus nidulans F23 & - & + \\
Aspergillus ochraceus F21 & - & + \\
Aspergillus ochraceus F57 & + & - \\
Aspergillus terreus F58 & + & - \\
Aspergillus ustus F22 & - & + \\
Alternaria consortialis F10 & - & + \\
Alternaria consortialis F50 & - & + \\
\hline
\end{tabular}

and safer environment with higher biological diversity $[13,29,30]$. Nevertheless, in our study the fungal abundance and richness were probably positively affected by the presence of water and humidity due to irrigation in the conventional orchard. These data are consistent with studies that suggest dew duration and relative humidity are critical parameters for predicting the fungal biomass of the soil [31, 32].

Insect cadavers displayed greater species diversity than soil samples, with 16 different species versus 5 species, respectively. Among the 16 insect-derived species, 15 (93.7\%) were found only in olive fly or olive psyllid cadavers, namely $A$. consortialis, A. niger, A. ochraceus, $A$. tamarii, A. terreus, C. cladosporioides, $C$. halotolerans, $C$. sphaerospermum, F. solani-like, L. aphanocladii, P. chrysogenum, P. crustosum, P. freii, P. polonicum and P. verruculosum, whereas, the Aspergillus species A. calidoustus, A. nidulans, $A$. pseudodeflectus, and $A$. ustus were found only in soil.

\section{Biotechnological properties of fungal isolates Enzymatic activities}

Not all isolates of the same fungal species necessarily produce the same enzyme and have the same intensity of the enzymatic activities. These properties are strain dependent [33]. In fact, the enzymatic production differs among fungi and is related to their natural habitat or ecological niche [34].

Our results showed that amylolytic activity was the most common among all our collected strains. These results are consistent with previous studies showing that amylase was the predominant secreted enzyme of endophytic fungi isolated from soybean [35]. Moreover, Penicillium species have been reported to be prominent producers of amylolytic activities [36], as is the case for
Aspergillus fungi isolated from different seeds, soils or from Morinda citrifolia [37-40]. Consistently, among the fungal isolates investigated in this study, those belonging to the genera Aspergillus and Penicillium were the most prominent amylase producers.

In addition to the amylolytic activity, Aspergillus was significantly the most abundant genus producing protease and lipase activities as compared to the other genera identified here. Consistently, previous studies with 110 fungal isolates of Aspergillus, Fusarium, Cladosporium and other genera had revealed that $73 \%$ of them produced protease, lipase and urease [41]. Predominant among the lipase and protease producing isolates were Aspergillus sp., Cladosporium sp., Myrothecium sp. and Fusarium sp..

In addition to their well-established nutritional function [36], amylase, protease and lipase activities could play an important role in fungal ecology and during microbial infection exhibiting antagonistic, entomopathogenic, and phytopathogenic features. Secreted enzymes such as amylases, proteases and lipases are known to be implicated in the interaction between insect hosts and entomopathogenic fungi. Lipases are involved in the adhesion of fungal spores on the insect cuticle, amylase allows degradation of glycogen from insect tissues for growth and invasion, and proteolytic degradation has been identified as a key factor in fungal pathogenesis, including several species of Aspergillus [36] and the infective degradation of proteinaceous material of the host cuticle by infection hyphae of entomopathogenic fungi $[21,22]$.

\section{Antagonistic activity}

Increasing antifungal activity is a potentially useful and effective strategy for fungal biocontrol. A fungal biocontrol agent may act against fungal pathogens by using antibiosis which is defined as the capacity of producing different antibiotics probably involved in the suppression of competitors. This mode of action is exercised by a broad number of fungal bio-controllers [42]. Moreover, other studies reported that the antagonistic activity of fungi were associated to competition for nutrients and space [43-45].

In this study, fungal isolates have clearly shown their antagonistic properties against the six tested fungal reference strains. Antagonistic activity of Penicillium species against these fungi was characterized by the production of toxic metabolites. According to previous reports, filamentous fungi, including some of the strains tested in our study as Penicillium chrysogenum F49', Aspergillus ochraceus F57 and Fusarium solani-like F59 may restrict and stop fungal growth. These filamentous fungi such as Aspergillus and Penicillium are known as antimicrobial due to their ability to produce toxic 
secondary metabolites including hydrolytic enzymes such as protease, amylase and lipase [46].

The susceptibility of Alternaria consortialis to 14 of the fungal isolates as, e.g., Penicillium chrysogenum, Penicillium crustosum, Penicillium pinophilum, and Penicillium polonicum tested in this study is consistent with previous studies reporting the antagonistic activity of antifungal compounds produced by Penicillium sp., (Macropherin A, Atrpinin A, Botryodiplodin and Brefeldin A) which allowed the inhibition of Alternaria sp. [3, 47].

\section{Entomopathogenic activity}

From the fungal taxa identified in this study, Aspergillus pseudodeflectus F13 and Lecanicillium aphanocladii F28' were found highly pathogenic to Ephestia kuehniella larvae. Previous studies have associated Aspergillus pseudodeflectus with entomopathogenic activity and the stimulation of fungal aflatoxin production by the insect host. It has been shown that the addition of aflatoxin to the food of insect larvae kills them and promotes the growth of the fungus [48, 49]. Consequently, experiments to evaluate its infecting ability towards vertebrates have to be performed.

According to our knowledge, Lecanicillium aphanocladii fungi have not previously been recorded in association with olive pests. Isolate $L$. aphanocladii F28' was characterized as a potent entomopathogen causing a high percentage (75\%) of larvalmortality. L. aphanocladii has previously been found associated with diseased and dead lepidopteran insects [50], and there appears to be clear link between the isolation from insect cadavers and entomopathogenic activity. The insect surface sterilization before fungal isolation as well as insect susceptibility bioassays confirmed this activity. The efficiency of Lecanicillium aphanocladii to parasitize dipteran insects as, e.g., mosquito larvae has also been reported [51, 52]. Furthermore, Lecanicillium spp. was used for 15 commercial preparations.

\section{Phytopathogenic activity}

In addition to these potential biocontrol agents which have a role in limiting pests, other fungi have antagonistic features for limiting the occurrence of phytopathogenic fungi in olive groves. Among the phytopathogenic fungi we have identified Alternaria consortialis F50 which have showed vascular tissue browning. This is consistent with the previous identification of Alternaria species as the cause of olive spoilage and a disease on olive shoots grown under greenhouse conditions [13]. Moreover, isolate Alternaria consortialis $\mathrm{F} 50$ has been shown to display entomopathogenic activity against E. kuehniella (larval mortality of $66.6 \%$ ). These results are corroborated by the findings of previous studies reporting the efficiency of
Alternaria spp. as entomopathogenic fungi where the insect may ingest them through infected leaves [53].

Alternaria strains displaying entomopathogenic, but lacking phytopathogenic activity could be used in pest management as whole organisms [54]. However, with both entomopathogenic and phytopathogenic activities being recorded as is the case for strain $A$. consortialis F50, investigation and identification of the insecticidal principle or mode of action could lead to the development of derived pest control agents not requiring application of the living fungus [55].

\section{Conclusions}

The present study describes for the first time the fungal diversity obtained from dead insect pests collected from Tunisian olive groves. The screening of secreted fungal enzymes showed highly variable activity profiles which might have impact for improving technological processes. With respect to the possible development of biological control agents, $50 \%$ of the fungal species from our collection showed entomopathogenic or antagonistic activity and were not phytopathogenic as determined in terms of browning length on cortex and vascular tissues. From the fungal taxa identified in this study, Aspergillus pseudodeflectus F13 and Lecanicillium aphanocladii F28' appear the most noticeable as they combine high entomopathogenic potential with lack of phytopathogenic activity against olive trees and - in the case of A. pseudodeflectus - antagonistic activity against phytopathogenic fungi. As endemic isolates well adapted to the regional climatic conditions, these strains could be promising in view of the development of protection of olive orchards after their insecticidal bioassays on the olive major pests.

\section{Methods}

Field sites and fungal isolation

Samples were randomly collected from 2 different olive groves located in two distinct geographical zones (Taous and Torba) of Sfax governorate, Tunisia (GPS coordinates: $\left(34^{\circ} 55^{\prime} 17^{\prime \prime} \mathrm{N}, 10^{\circ} 36^{\prime} 47^{\prime \prime} \mathrm{W}\right.$; $34^{\circ} 50^{\prime} 56.9^{\prime \prime} \mathrm{N} 10^{\circ} 27^{\prime}$ 33.6"E). These samples were collected once per month in the period ranging from December 2016 to February 2017. At each site, around twenty olive fruits and twenty branches infested respectively by the olive fly, B. oleae, and the olive psyllid, E. olivine, as well as $100 \mathrm{~g}$ of soil (from $10 \mathrm{~cm}$ of the upper soil layer) were sampled from two sampling locations within the olive orchards. Each sample was packaged in a sterile plastic bag $(31 \times 20$ $\mathrm{cm})$, transported to the laboratory under aseptic conditions and stored at $4{ }^{\circ} \mathrm{C}$ until the isolation procedure of fungi was carried out. The olive orchards were chosen according to the pest and pathogen management strategy practiced: Whereas the experimental plot at Taous 
was maintained under conventional control measures and in irrigated, the Torba plot was conducted according to the organic farming system under rain-fed conditions.

Sampled insect cadavers were surface sterilized in a $70 \%$ ethanol solution for $1 \mathrm{~min}$ in laminar chamber. The surface-sterilized insects were rinsed 3 times with sterile water for $1 \mathrm{~min}$ and blotted dried on sterile paper towels. Each sample was ground using a micro-pestle in sterilized distilled water. The soil samples were treated as follows: $10 \mathrm{~g}$ of soil was dissolved in $90 \mathrm{ml}$ of sterile distilled water and mixed with a stomacher. Supernatants were diluted 10 -fold and $100 \mu \mathrm{l}$ of each dilution was spread on the potato dextrose agar media (PDA: $4 \mathrm{~g}$ $\mathrm{l}^{-1}$ Potato extract, $20 \mathrm{gl}^{-1}$ Dextrose, $16 \mathrm{gl}^{-1}$ Agar). A total of 34 pure fungal cultures were isolated after continuous sub-cultivation. The pure cultures were recorded and maintained on PDA in active form for further investigation. For long-term storage, the fungal colonies were stored in paraffin oil at $-20^{\circ} \mathrm{C}$.

\section{Identification of fungal isolates}

The isolates were initially identified based on morphological structures (color, texture of the mycelia and spore formation) performed under microscopic observation of fresh cultures [56]. For fungal DNA extraction, the mycelial mass obtained from the culture plate was placed in a $2 \mathrm{ml}$ tube, submerged in liquid nitrogen and then ground using a micro-pestle in lysis buffer. The extraction protocol is continued using the DNeasy Plant Mini kit (Qiagen ${ }^{\circ} \mathrm{GmbH}$, Hilden, Germany) following manufacturer's instructions. The quality of the genomic DNA was evaluated by a NanoDrop NT-100 UV spectrophotometer (NanoDrop technologies ${ }^{\circ}$, Montchanins, USA).

Molecular identification of isolates was made by PCR amplification of the internal transcribed spacer (ITS) region of the nuclear rRNA operon comprising both the ITS1 and ITS2 elements separated by the 5.8S rRNA gene [57] using the fungal specific primers ITS5 (5'GGAAGTAAAAGTCGTAACAAGG-3') and ITS4 (5'TCCTCCGCTTATTGATATGC-3') [58]. The amplification was performed in $50 \mu \mathrm{l}$ reaction volume mixture containing $42.25 \mu \mathrm{l}$ of $\mathrm{H}_{2} \mathrm{O}, 5 \mu \mathrm{l}$ of Taq PCR Buffer (10X), $1 \mu \mathrm{l}$ of dNTPs mix $(200 \mu \mathrm{M}), 0.25 \mu \mathrm{l}$ of each primer $(0.4 \mu \mathrm{M}), 0.25 \mu \mathrm{l}$ of Taq Polymerase (1.25 units/ $50 \mu \mathrm{l} \mathrm{PCR})$ (New England Biolabs ${ }^{\circ}$, Germany) and $1 \mu \mathrm{l}$ DNA template. The PCR was performed as follows: initial denaturing step at $95^{\circ} \mathrm{C}$ for $3 \mathrm{~min}$, followed by 35 cycles of $95^{\circ} \mathrm{C}$ for $45 \mathrm{~s}, 52^{\circ} \mathrm{C}$ for $45 \mathrm{~s}$, and $68^{\circ} \mathrm{C}$ for $2 \mathrm{~min}$, and a final extension step at $68^{\circ} \mathrm{C}$ for $5 \mathrm{~min}$. PCR products were isolated by electrophoresis on a $1 \%$ agarose gel and purified using PCR Purification Kit (Qiagen ${ }^{\circ} \mathrm{GmbH}$, Hilden, Germany) following the manufacturer's instructions.

\section{Phylogenetic analysis}

The amplified ITS products were sequenced using ITS4 and ITS5 primers. Sequencing was performed by Starseq ${ }^{\circ} \mathrm{GmbH}$ (Mainz, Germany). The ITS sequence information was used to match the most closely related fungal isolates with the NCBI BLAST algorithm from the GenBank database (http://www.ncbi.nlm.nih.gov). The analysis of the ITS sequences were performed using the MEGA 6 program [59] (http://www.megasoftware.net).

\section{Screening for extracellular enzyme production}

Qualitative tests were used to evaluate the production of fungal extracellular enzymes of interest in industrial biotechnology. The screened enzymes were lipase, protease and amylase.

Lipase production was tested on PDA (1 l) supplemented with olive oil $(16.0 \mathrm{ml})$, and Rhodamin solution $\left(10 \mathrm{mg} \mathrm{ml}^{-1}\right.$ ) (Sigma Aldrich', Germany). After development of the isolates on agar at optimal conditions, lipase activity was detected by irradiating with Ultra Violet light at $350 \mathrm{~nm}$. Positive reaction is accompanied by the presence of precipitates around the fungal colony [60].

Protease production was revealed on skim milk agar. To determine the proteolytic potential, fungi were grown at $25^{\circ} \mathrm{C}$ for $72 \mathrm{~h}$. The enzyme production was assessed by the appearance of a clear zone corresponding to casein hydrolysis surrounding the fungal colony [61].

To check for amylase activity, fungi were incubated in PDA medium supplemented with starch (1\%). After incubation and fungal growth an iodine solution $(0.3 \mathrm{~g}$ iodine and $0.6 \mathrm{~g} . \mathrm{l}^{-1}$ ) was added to the plate. Amylase production is shown by the presence of a clear halo due to the degradation of starch and failure to form the colored starch-iodine intercalation complex [62].

\section{Detection of antagonistic activity in vitro}

The in vitro antagonistic activity of the collected fungal isolates was tested against the following pathogenic fungi provided by the Olive Tree Institute: Aspergillus calidoustus, Aspergillus pseudodeflectus, Aspergillus tamarii, Alternaria consortialis and Penicillium chrysogenum. These latter represent known pathogens of the olive tree and are, therefore, main target organisms for biocontrol in olive orchards.

The antagonism assays were conducted using dualculture tests. Petri dishes containing PDA medium were first inoculated with the conidia of an actively growing fresh fungal culture. The fungal suspension was standardized to approximately $10^{6}$ conidia/ml using Malassez lame under microscope (Leitz Dialux $940 \mathrm{~EB}$ ). They were obtained by scraping conidia from 15-day-old cultures of fungal isolates on PDA into an aqueous solution of $2 \%$ Tween 80 then filtered through cheesecloth to remove mycelium. $100 \mu \mathrm{l}$ of each fungal suspension was spread 
onto the surface of the Petri dishes. Then, mycelial disc (10 $\mathrm{mm}$ in diameter) cut from the antagonistic fungal culture was positioned in the center of the plate and incubated at $25^{\circ} \mathrm{C}$ in the dark for 7 days. The assay was concluded when the pathogen's radial growth reached the antagonist. The only type of interaction monitored was the antibiosis determined by the presence of inhibition zones, which was measured and considered as indication for antifungal activity.

\section{Screening for Entomopathogenic activity}

The pathogenicity of fungal isolates was tested on the factitious host Ephestia kuehniella Zeller (Lepidoptera: Pyralidae). This moth was reared on whole wheat semolina in the Laboratory of Improvement and Protection of Olive Tree Genetic Resources, Olive Tree Institute (Sfax, Tunisia). Fourth instar larvae were used for fungal susceptibility tests. For each assay, 10 larvae were fed with $1 \mathrm{~g}$ of semolina mixed with $500 \mu \mathrm{l}$ of a culture suspension $\left(1 \times 10^{7}\right.$ conidia $\left.\mathrm{ml}^{-1}\right)$. The conidial suspension of each fungal strain was determined under the microscope using a Neubauer hemocytometer and adjusted to the cited concentration; a diet with $1 \mathrm{~g}$ sterile semolina mixed with $500 \mu \mathrm{l}$ of sterile water was used as the control. Three replicates were performed for each fungal isolate, including the control [46]. The cumulative mortality was recorded by counting the number of dead larvae after 7 days of incubation under controlled conditions (temperature $22-25^{\circ} \mathrm{C}, 70 \pm 10 \% \mathrm{RH}$, natural light). To satisfy Koch's postulates, the dead larvae were treated as follow: firstly, larval cadaver surfaces were sterilized with $5 \%$ sodium hypochlorite, rinsed twice and dried on filter paper, then incubated at $25^{\circ} \mathrm{C}$ under saturating conditions to allow the development of the tested fungi on the surface of the insect cadaver. The conformity of our results was justified after the tested fungi grew, were transferred to fresh PDA medium and incubated at $25^{\circ} \mathrm{C}$. The obtained fungi were determined by microscopy (Leitz Dialux $40 \mathrm{~EB}$ ).

Data were analyzed using ANOVA and values (mean \pm standard error) were compared using Tukey test and differences were statistically significant at $p<0.05$. Statistical analyses were performed using SPSS software for version 19.0 (SPSS Inc., Chicago).

\section{Evaluation of Phytopathogenic activity}

Phytopathogenic activity of fungal isolates against olive trees was evaluated using the excised shoot assays [63]. Shoots of approximately $250 \mathrm{~mm}$ length and $15 \mathrm{~mm}$ diameter were collected from olive trees. Shoot surfaces were sterilized for $10 \mathrm{~min}$ with $10 \%$ sodium hypochlorite solution rinsed with sterile water and dried using sterile paper towels. A plug of the same size $(5 \times 5 \mathrm{~mm})$ of 7 days-old colony was incubated in the middle of the shoot after removing the cortex flap $(5 \times 8 \mathrm{~mm})$ by a sterile scalpel. Five shoots were inoculated with each isolate. Inoculated shoots were then kept at $28-32^{\circ} \mathrm{C}, 70 \pm$ $10 \% \mathrm{RH}$, natural light for 28 days. The assays were performed in 5 replicates. To reveal the trunk browning, the bark of the inoculated shoots was scraped with a sharp knife. Inoculated shoots were longitudinally cut at whole length into two halves in order to check wood browning in the internal vascular tissues. To comply with Koch's postulates, sections of brown tissues were cultured on PDA and incubated at $25^{\circ} \mathrm{C}$ for 7 days. Fungal cultures that grew up were identified microscopically (Leitz Dialux 40 EB).

\section{Supplementary information}

Supplementary information accompanies this paper at https://doi.org/10 1186/s12866-020-01997-z

Additional file 1: Supplementary Figure 1. Taous is an experimental orchard of the Olive Tree Institute, with an area of 126 ha. It contains olive, almond and pistachio fields. Olive cultivations include several varieties. In this study, insects were sampled from the variety Chemlali grown under artificial irrigation. The plantation density is 69 plants per hectare, with a spacing of $12 \times 12 \mathrm{~m}$. Regular monitoring of the major olive pests is performed and organophosphate contact insecticides are applied if required. Torba is a private olive orchard with an area of 50 ha. Insects and soil were sampled from the olive cv. Chemlali cultivated under rainfed conditions. The density of plantation is 17 plants per hectare, with spacing of $24 \times 24 \mathrm{~m}$. Regular monitoring of the major olive pests is performed and mass trapping is conducted if required. The Images depicted in Figure are our own.

Additional file 2: Supplementary Figure 2. Sunburst chart showing the total relative abundance of fungal species and their corresponding family detected in two olives orchards in Tunisia.

\section{Abbreviations}

ITS: Internal Transcribed Spacer; DNA: Deoxyribonucleic acid; e.g.: Exempli gratia; UV: Ultraviolet; PDA: Potato Dextrose Agar; PCR: Polymerase Chain Reaction; rRNA: Ribosomal ribonucleic acid

\section{Acknowledgements}

We are greatly indebted to The National Agency for the Promotion of Scientific Research (ANPR) of Tunisia is a public agency under supervision of The Ministry of Higher Education and Scientific Research.

\section{Declarations}

Not applicable.

\section{Authors' contributions}

Planning of experiments: $\mathrm{HG}, \mathrm{KH}, \mathrm{IK}, \mathrm{CS}$ and $\mathrm{AL} /$ Providing the field work and experimentations HG, IK SN and NA/ Manuscript redaction and data interpretation: $\mathrm{HG}$ and $\mathrm{KH}$ Correction of the manuscript with scientific advice: AL, MK, IK, CS, MT and KH. All authors have read and approved the manuscript.

\section{Funding}

The authors acknowledge receipt of funding from the German Academic Exchange Service (DAAD) under research grants 57166691, 57247235, and 57401859 (project "BIOlive") and 57477362 (project "BioPunica") financed from the budget of the Federal Foreign Office, from the Ministry of Higher Education and Scientific Research, Tunisia, and from the Institution of Agricultural Research and Higher Education, Tunisia (IRESA),

\section{Availability of data and materials}

The datasets used and/or analysed during the current study are available from the corresponding author on reasonable request. 


\section{Ethics approval and consent to participate}

Mr. Mohieddine Ksantini, Professor and Director of the Tunisian Olive Institute, have authorized the sampling in this work which was done from 2 different olive groves located in two distinct geographical zones of Sfax governorate, Tunisia.

\section{Consent for publication}

Not applicable.

\section{Competing interests}

The authors declare no conflict of interest.

\section{Author details}

'Laboratory of Improvement and Protection of Genetic Resources of Olive Tree, Tunisian Olive Institute, University of Sfax, Airport Road, P.B. 1087, 3000 Sfax, Tunisia. ${ }^{2}$ University of Sousse, Higher Institute of Agronomic Sciences of Chott Meriem, 4042 Sousse, Tunisia. Institute for Microbiology and Biochemistry, Geisenheim University, Geisenheim, Germany. ${ }^{4}$ Department of Biology, Technische Universität Darmstadt, Darmstadt, Germany.

Received: 13 March 2020 Accepted: 5 October 2020

Published online: 12 October 2020

\section{References}

1. Debbi A, Boureghda H, Monte E, Hermosa R. Distribution and genetic variability of Fusarium oxysporum associated with tomato diseases in Algeria and a biocontrol strategy with indigenous Trichoderma spp. Front Microbiol. 2018;9:282.

2. Gharsallah H, Ksentini I, Abdelhedi N, Naayma S, HadjTaieb K, Sahnoun M, Triki MA, Ksantini M, Leclerque A. Screening of bacterial isolates related to olive orchard pests in Tunisia using 165 ribosomal RNA and evaluation of their biotechnological potential. J Appl Microbiol. 2019;126:489-502.

3. Hadj Taieb K, Gharsallah H, Ksentini I, Schuster C, Fernández Bravo M, Garrido Jurado I, Quesada Moraga E, Leclerque A, Triki MA, Ksantini M. Phytopathogenic and antagonistic potentialities of fungi associated with pistachio bark beetle, Chaetoptelius vestitus (Coleoptera, Curculionidae), infesting pistachio (Pistacia vera) in Tunisia. J Appl Microbiol. 2019;126:1821-34.

4. Mugnai L, Bridge PD, Evans HC. A chemotaxonomic evaluation of the genus Beauveria. Mycol Res. 1989;92:199-209.

5. Kryukov VY, Yaroslavtseva ON, Levchenko MV, Lednyov GR, Glupov W. Phenotypic variability of environmental isolates of the entomopathogenic fungus Beauveria bassiana. Microbiol. 2010;79:265-9.

6. FAOSTAT (2016) Agricultural production database. Available online at: http://faostat.fao.org/.

7. Gucci R, Fereres E (2012) "Fruit trees and vines. Olive," in Crop Yield Response to Water. FAO Irrigation and drainage paper 66 (Rome: Food and Agriculture Organization of the United Nations) 300-313.

8. Tunisian Ministry of Agriculture, 2019). Agridata :http://www.agridata.tn/ [last accessed 14/05/2020].

9. Official Journal of the International Olive Council. 2017. Issue No 124.

10. Pelerents $C$ (1980). The contribution of the European community in the domain of integrated control. In proceedings of the National International Symposium of the IOBCMPRS on integrated control in agriculture and forestry ed. Russ K and Berger H pp. 383-386, Vienna.

11. Fiori G (1982) Proceedings of the second meeting on Dacus oleae (Gmel.), Perugia, Frustula Entomol vol. 4.

12. Ramos P, Campos M, Ramos J. Long-term study on the evaluation of yield and economic losses caused by Prays oleae Bern. Olive Crop Granada (Southern Spain). 1998;17:645-7.

13. Oliveira I, Pereira JA, Lino-Neto T, Bento A, Baptista P. Fungal diversity associated to the olive moth, Prays Oleae Bernard: a survey for potential Entomopathogenic Fungi. Microb Ecol. 2012;63:964-74.

14. Triki MA, Rhouma A, Khabou W, Boulila M, loos R (2009) Recrudescence du dépérissement de l'olivier causé par les champignons telluriques en Tunisie. In: Proceeding of Olivebioteq.

15. Gharbi Y, Triki MA, Jolodar A, Trabelsi R, Gdoura R, Daayf F. Genetic diversity of Verticillium dahliae from olive trees in Tunisia based on RAMS and IGSRFLP analyses. Can J Plant Pathol. 2014;36:491-500.

16. Lacey L, Frutos R, Kaya H, Vail P. Insect pathogens as biological control agents: do they have a future? Biol Control. 2001;21:230-48.
17. Lorini I, Galley DJ. The cross-resistance Spectrum in Deltamethrin resistance strains of Rhyzopertha dominica (F.) (Coleoptera: Bostrychidae). Neotrop Entomol. 2001;30(2):321-5.

18. Carvalho GA, Godoy MS, Parreira DS, Rezende DT. Effect of chemical insecticides used in tomato crops on immature Trichogramma pretiosum (Hymenoptera: Trichogrammatidae). Rev Colomb Entomol. 2010;36(1):10-5.

19. Ksentini I, Jardak T, Zeghal N. Bacillus thuringiensis, deltamethrin and spinosad side-effects on three Trichogramma species. Bull Insectol. 2010; 63(1):31-7.

20. Nicolopoulou-Stamati P, Maipas S, Kotampasi C, Stamatis P, Hens L. Chemical pesticides and human health: the urgent need for a new concept in agriculture. Front Public Health. 2016;4:148.

21. Ali S, Huang Z, Ren SX. Production and extraction of extracellular lipase from the entomopathogenic fungus Isaria fumosoroseus (Cordycipitaceae: Hypocreales). Biocontrol Sci Technol. 2009;19:81-9.

22. Mondal S, Baksi S, Koris A, Vatai G. Journey of enzymes in entomopathogenic fungi. Pac Sci Rev A: Nat Sci Eng. 2016:8:85-99.

23. Almeida F, Wolf JM, da Silva TA, DeLeon-Rodriguez CM, Patini Rezende C, Moreira Pessoni A, Freitas Fernandes F, Silva-Rocha R, Martinez R, Rodrigues ML, RoqueBarreira MC, Casadevall A. Galectin-3 impacts Cryptococcus neoformans infection through direct antifungal effects. Nat Commun. 2017:8:1968.

24. Al-Aidroos K, Seifert AM. Polysaccharide and protein degradation, germination, and virulence against mosquitoes in the entomopathogenic fungus Metarhizium anisopliae. J Invertebr Pathol. 1980;36:29-34.

25. Hongsanan S, Jeewon R, Purahong W, Xie N, Liu JK, Jayawardena RS, Ekanayaka AH, Dissanayake A, Raspe' O, Hyde KD, Stadler M. Can we use environmental DNA as holotypes? Fungal Divers. 2018;92:1-30.

26. Godinho VM, Gonçalves VN, Santiago IF, Figueredo HM, Vitoreli GA, Schaefer CEG. Diversity and bioprospection of fungal community present in oligotrophic soil of continental Antarctica. Extremophiles. 2015;19:585-96.

27. Yee TL, Tajuddin R, Mohamed N, Mohd MH, Zakaria L. Filamentous ascomycete and basidiomycete fungi from beach sand. Rendiconti Lincei. 2016;27:603-7.

28. Kazerooni EA, Maharachchikumbura SSN, Rethinasamy V, Al-Mahrouqi H, AlSadi AM. Fungal diversity in tomato Rhizosphere soil under conventional and desert farming systems. Front Microbiol. 2017:8:1462.

29. Sun B, Yu H, Chen A, Liu X. Insect-associated fungi in soils of field crops and orchards. Crop Prot. 2008;27:1421-6.

30. Mander U, Mikk M, Külvik M. Ecological and low intensity agriculture as contributors to landscape and biological diversity. Landsc Urban Plan. 1999;46:169-77.

31. Timmer LW, Darhower HM, Zitko SE, Peever TL, Ibanez AM, Bushong PM. Environmental factors affecting the severity of Alternaria brown spot of citrus and their potential use in timing fungicide applications. Plant Dis. 2000;84:638-43.

32. Sharon MT, Coley PD, Kursar TA. The effects of weather on fungal abundance and richness among 25 communities in the intermountain west. BMC Ecol. 2002;2:7.

33. Arévalo Villena M, Úbeda Iranzo JF, Cordero Otero RR, Briones Pérez Al. Optimization of a rapid method for studying the cellular location of $\beta$ glucosidase activity in wine yeasts. J Appl Microbiol. 2005;99:558-64.

34. Sunitha VH, Devi Nirmala D, Srinivas C. Extracelullar enzymatic activity of endophytic fungal strains isolated from medicinal plants. World J Agric Sc 2013;9:1-9.

35. Wenzel JB. Enzymatic and antimicrobial activity of endophytic fungi isolated from soybean. Pesq. Online: Biol aHealth. 2013;9:1-15.

36. Sobral LV, Melo KN, Souza CM, Silva SF, Silva GLR, Silva ALF, Wanderley KAA, Oliveira IS and Cruz R (2017) Antimicrobial and enzymatic activity of anemophilous fungi of a public university in Brazil. Anais da Academia Brasileira de Ciências (annals of the Brazilian Academy of Sciences).

37. Varalakshmi KN, Kumudini BS, Nandini BN, Solomon J, Suhas R, Mahesh B, Kavitha AP. Production and characterization of a-amylase from Aspergillus niger JGI 24 isolated in Bangalore. Polish J Microbiol. 2009;58:29-36.

38. Mishra BK, Dadhich SK. Production of amylase and xylanase enzymes from soil fungi of Rajasthan. J Adv Dev Res. 2010;1:21-3.

39. Tripathy SS, Dash S, Gupta N. Screening \& selection of some fungi for production of extracellular amylase. Ind J Fund Appl Life Sci. 2011;1:131-6.

40. Tavares ACD, Fonseca JS, Fonseca TRB, Barroncas JF, Souza RAT, Silva TA, Teixeira MFS. Extracellular enzymes of anamorphic fungi isolated from Morinda citrifolia I. Biochembiotecnol Rep. 2012;1:1-6.

41. Aboul-Nasr MB, aboul-naser AZ, Amer EM. Enzymatic and toxigenic ability of opportunistic fungi contaminating intensive care units and operation rooms at Assiut University hospitals, Egypt. Springer Plus. 2013;2:347-57. 
42. Demirci E, Dane E, Eken C. In vitro antagonistic activity of fungi isolated from sclerotia on potato tubers against Rhizoctonia solani. Turk J Biol. 2011;32:457-62.

43. Spadaro D, Vola R, Piano S, Gullino ML. Mechanisms of action and efficacy of four isolates of the yeast Metschnikowia pulcherrima active against postharvest pathogens on apples. Postharvest Biol Technol. 2002;24:123-34.

44. Spadaro D, Gullino ML. State of the art and future prospects of the biological control of postharvest fruit diseases. Int J Food Microbiol. 2004;91:185-94.

45. Kapetanakou AE, Kollias JN, Drosinos EH, Skandamis PN. Inhibition of A. carbonarius growth and reduction of ochratoxin a by bacteria and yeast composites of technological importance in culture media and beverages. Int J Food Microbiol. 2012;152:91-9.

46. Boukedi H, Sellami S, Ktari S, Belguith-Ben Hassana N, Sellami-Boudawara T, Tounsi S, Abdelkefi-Mesrati L. Isolation and characterization of a new Bacillus thuringiensis strain with a promising toxicity against Lepidopteran pests. Microbiol Res. 2016;186:9-15.

47. Bladt TT, Frisvad JC, Knudsen PD, Larsen TO. Review on anticancer, antifungle compound from Aspergillus, Penicillium, other filamentous fungi. Molecules. 2013;18:11338-76.

48. Milton TD, Lazzaro BP, Brown DL, Carbone I, Milgroom MG (2017) Balancing selection for aflatoxin in Aspergillus flavus is maintained through interference competition with, and fungivory by insects Procceedings biological sciences society DOl:https://doi.org/10.1098/rspb.

49. Dengler R (2017) Bugs may be causing a common crop mold to produce a deadly toxin [archive], Science news.

50. Pečiulyte D, Kačergius A. Lecanicillium aphanocladii - a new species to the mycoflora of Lithuania and a new pathogen of tree leaves mining insects. Bot Lithuanica. 2012;18:133-46.

51. Lopez Lastra C, Garcia J and Micieli M (2002) Microecology of entomopathogenic fungi from aquatic environments. Londrina, Brazil: Embrapa Soja 184: 83-85.

52. El-Debaiky SAK. New record of Lecanicillium aphanocladii family: Cordycipitaceae from Egypt. J Bacteriol Mycol. 2017;5.

53. Sharma I, Sharma A. Use of Alternaria Spp as a Pest control agent : a review. World Appl Sci J. 2014;31(11):1869-72.

54. Sharma A, Thakur A, Kaur S, Pati PK. Effect of Alternaria alternata on the coccinellid pest Henosepilachna vigintioctopunctata and its implications for biological pest management. J Pest Sci. 2012;85:513-8.

55. Hadj Taieb K, Gharsallah H, Ksentini I, Leclerque A, Schuster C, Cheffi M, Naayma S, Triki MA, Ksantini M. Screening of biological activities of fungi associated with pistachio bark beetle, Chaetoptelius vestitus (Coleoptera, Curculionidae), infesting pistachio cultivations in Tunisia. J Appl Microbiol. 2020;128:1472-85.

56. Dai FL (1987) Morphology and classification of Fungi (1st edn), Scientific \&Technological Press pp. 297-314.

57. Sette LD, Passarini MRZ, Delarmelina C, Salati F, Duarte MCT. Molecular characterization and antimicrobial activity of endophytic fungi from coffee plants. World J Microbiol Biotechnol. 2006;22:1185-95.

58. White TJ, Bruns T, Lee S, Taylor J (1990) Amplification and direct sequencing of fungal ribosomal RNA genes for phylogenies. In PCR protocols. A guide to methods and applications. Ed Innis MA, Gelfand DH, Sninsky JJ and White TJ pp. 315-322. Academic Press, New York, U.S.A.

59. Tamura K, Stecher G, Peterson D, Filipski A, Kumar S. MEGA6: molecular evolutionary genetics analysis version 6.0. Mol Biol Evol. 2013;30:2725-9.

60. Thota P, Bhogavalli PK, Vallem PR, Sreerangam V. Screening and identification of potential fungal strains for the production of extracellular lipase from soil. Plant Sci. 2012;2:79-84.

61. Mohanasrinivasan V, Shankar V, Elizabeth R, Soumya AR, Devi CS. Isolation, screening and identification of protease producing fungi from rhizosphere soil and optimization of $\mathrm{pH}$, incubation time and inducer concentration for enhanced protease production. Int J Pharm Biol Sci. 2012;3:784-93.

62. Khan MJ, Qayyum S, Alam F, Husain Q. Effect of tin oxide nanoparticle binding on the structure and activity of a-amylase from Bacillus amyloliquefaciens. Nanotechnology. 2011;22:45.

63. Jeffers SN, Aldwinckle HS, Burr TJ, Arneson PA. Excised twig assay for the study of apple tree crown rot pathogens in vitro. Plant Dis. 1981;65:823-5.

\section{Publisher's Note}

Springer Nature remains neutral with regard to jurisdictional claims in published maps and institutional affiliations.

Ready to submit your research? Choose BMC and benefit from:

- fast, convenient online submission

- thorough peer review by experienced researchers in your field

- rapid publication on acceptance

- support for research data, including large and complex data types

- gold Open Access which fosters wider collaboration and increased citations

- maximum visibility for your research: over $100 \mathrm{M}$ website views per year

At BMC, research is always in progress.

Learn more biomedcentral.com/submissions 